\title{
Analisis Pembelajaran Daring di Masa Pandemi Covid-19 pada Kemampuan Technological Pedagogical And Content Knowledge (TPACK) Guru Sekolah Dasar
}

\author{
${ }^{*}$ Hariati ${ }^{1}$, M. Ilyas ${ }^{2}$, Mohammad Siddik ${ }^{3}$ \\ 1 Guru SDN 006 Benua Baru, Sangkulirang Kutai Timur, Indonesia \\ 1,2,3 FTIK, Universitas Mulawarman, Samarinda, Indonesia \\ Emil: hartati97@gmail.com (corresponding author)
}

\begin{tabular}{|c|c|}
\hline (A) Check for updates open 0 access (C) & DOI: https:/ / doi.org/10.53621/jider.v2i1.119 \\
\hline Informasi Artikel & ABSTRAK \\
\hline $\begin{array}{l}\text { Riwayat Artikel: } \\
\text { Diterima: } 05 \text { Februari } 2022 \\
\text { Revisi Akhir: } 20 \text { Februari } 2022 \\
\text { Disetujui: } 25 \text { Februari } 2022 \\
\text { Terbit: } 28 \text { Februari } 2022\end{array}$ & $\begin{array}{l}\text { Tujuan penelitian ini adalah pertama: Menganalisis pembelajaran daring } \\
\text { dengan kemampuan pengetahuan teknologi (TK) guru Sekolah Dasar. } \\
\text { Kedua: Menganalisis pembelajaran Daring dengan kemampuan pengetahuan } \\
\text { pedagogik (PK) guru Sekolah Dasar. Ketiga: Menganalisis Pembelajaran } \\
\text { Daring dengan kemampuan pengetahuan konten (CK) guru Sekolah Dasar. }\end{array}$ \\
\hline $\begin{array}{l}\text { Kata Kunci: } \\
\text { Pembelajaran daring, } \\
\text { Pandemi Covid-19, } \\
\text { TPACK, } \\
\text { Guru Sekolah Dasar. }\end{array}$ & $\begin{array}{l}\text { Penelitian dilaksanakan di SDN } 006 \text { Sangkulirang Kutai Timur, } \\
\text { pengumpulan data dengan menetapkan informan penelitian ini adalah para } \\
\text { guru yang memiliki kualifikasi guru yang menerapkan TPACK, dilakukan } \\
\text { pula observasi secara langsung serta wawancara mendalam dan tinjauan } \\
\text { dokumen sebagai data sekunder. Wawancara dengan menggunakan teknik }\end{array}$ \\
\hline & $\begin{array}{l}\text { wawancara terstruktur, dengan mempersiapkan pedoman wawancara, alat } \\
\text { bantu wawancara dengan buku catatan, rekaman audio dan atau kamera } \\
\text { smartphone. Teknik analisis data dengan model miles and Huberman, tiga } \\
\text { tahapan analisis kegiatan, yaitu data condensation, data display dan conclusion } \\
\text { /verifications. Hasil penelitian menemukan pada pengetahuan teknologi (TK) } \\
\text { bahwa guru mampu dan baik dalam menggunakan teknologi untuk } \\
\text { pembelajaran, sesuai kemampuan dan kondisi pembelajaran menggunakan } \\
\text { WhatsApp, Zoom meeting atau google classroom guru mampu } \\
\text { mendownload materi dari Internet atau website dan materi dari youtube dan } \\
\text { kemudian guru mampu membagikan dan menshare ke peserta didik dengan } \\
\text { menggunakan teknologi, guru sudah mengetahui manfaat dan keunggulan } \\
\text { teknologi, guru dapat melakukan interaksi dengan peserta didik pada } \\
\text { pembelajaran daring. Untuk kemampuan Pengetahuan Pedagogik (PK) guru } \\
\text { sudah baik dan tepat, karena guru mampu merancang perangkat } \\
\text { pembelajaran, guru mampu menggunakan media pembelajaran yang } \\
\text { menarik, Guru menyesuaikan karakter dengan metode yang digunakan serta } \\
\text { Guru melakukan evaluasi pembelajaran. Sedangkan pada kemampuan } \\
\text { pengetahuan konten (CK) adalah sudah baik dan mampu, yakni guru } \\
\text { memiliki kemampuan yang baik, guru mampu menyusun materi atau bahan } \\
\text { ajar dan Guru menggunakan sumber belajar berbasis teknologi. }\end{array}$ \\
\hline
\end{tabular}

\section{PENDAHULUAN}

Covid-19 telah menimbulkan dampak yang sangat serius dalam kehidupan manusia. Sejak pertama kali ditemukan di kota Wuhan, Propinsi Hubei, Tiongkok pada bulan Desember 2019, telah banyak menimbulkan korban. Jumlah kasus positif covid-19 tercatat kasus covid-19 di Indonesia menjadi 2.417.788 sejak terkonfirmasi pada 2 Maret 2020 lalu. Data tersebut dirilis dalam website resmi Satuan Tugas Penanganan Covid-19 Indonesia, (covid-19.go.id) diakses pada tanggal 7 Juli 2021.

Tingginya kasus covid-19 tersebut mendorong pemerintah mengeluarkan kebijakan social distancing/ PPKM pada semua lapisan masyarakat. Kebijakan tersebut memberikan dampak terhadap pendidikan di Indonesia khususnya pada proses pembelajaran bagi Peserta Didik. Pada tanggal 24 Maret 2020, Menteri Pendidikan dan Kebudayaan Republik Indonesia mengeluarkan surat edaran tentang Pelaksanaan Kebijakan Pendidikan Dalam Penyebaran Corona Virus Disease 
(Covid-19), yang salah satu poinnya adalah menjelaskan tentang proses pembelajaran dari rumah yang dapat dilakukan secara daring (dalam jaringan) dan/atau secara luring (luar jaringan). Surat edaran tersebut diperkuat lagi dengan terbitnya surat edaran Sekretaris Jenderal Pendidikan Dan Kebudayaan Republik Indonesia nomor 15 tahun 2020 tanggal 8 Mei 2020 tentang Pedoman Penyelenggaraan Belajar Dari Rumah Dalam Masa Darurat Penyebaran Corona Virus Disease (Covid-19). BDR dilaksanakan dengan Pembelajaran Jarak Jauh (PJJ) yang dibagi dalam 2 (dua) pendekatan yakni pembelajaran jarak jauh dalam jaringan (daring) dan pembelajaran jarak jauh luar jaringan (luring) (Wilson, 2020).

Dalam Undang-Undang No.20 tahun 2003, pasal 1 ayat 15, dijelaskan bahwa PJJ adalah pendidikan yang peserta didiknya terpisah dari guru dan pembelajarannya menggunakan berbagai sumber belajar melalui teknologi komunikasi, informasi dan media lain. Berdasarkan data UNESCO tanggal 19 Maret 2020, terdapat 112 negara yang telah menerapkan kebijakan belajar dari rumah, antara lain Malaysia, Thailand, Jerman, Austria, Meksiko, Afrika Selatan, Yaman, dan Zambia. Dari 112 negara tersebut, 101 negara telah menerapkan kebijakan belajar dari rumah secara nasional. Sementara 11 negara lainnya, termasuk Indonesia menerapkan belajar dari rumah di wilayah-wilayah tertentu (bebas, kompas.id, 31 Maret 2020), diakses tanggal 27 Juni 2021. Di Indonesia PJJ telah berlangsung sejak 16 Maret 2020 dan terus diperpanjang dengan mempertimbangkan situasi masing-masing daerah. Perubahan proses pembelajaran dari tatap muka ke PJJ membawa tantangan tersendiri baik bagi peserta didik, guru pada proses PJJ dengan pendekatan pembelajaran daring.

Belajar yang dilakukan secara mandiri sangat diperlukan dalam pembelajaran daring, karena ketika proses pembelajaran, peserta didik akan mencari, menemukan sampai dengan menyimpulkan sendiri yang telah ia pelajari (Handarini \& Wulandari, 2020), banyak manfaat pula dirasakan dengan pembelajaran daring, antara lain menghemat waktu, biaya, sangat efektif dalam penyampaian karena memiliki kemampuan memperbaharui, menyimpan, mendistribusikan, dan membagi materi pengajaran atau informasi dianggap mampu menjawab permasalahan belajar (Erni et al., 2020), pembelajaran daring sekitar $89 \%$ berminat dan $78 \%$ setuju bahwa dalam penerapannya dinilai lebih efektif daripada pembelajaran konvensional (Sofyana \& Rozaq, 2019), bahwa dampak COVID-19 terhadap implementasi pembelajaran daring di SD dapat terlaksana dengan cukup baik apabila adanya kerja sama antara guru, siswa dan orang tua dalam belajar di rumah (Dewi, 2020).

Namun dalam pelaksanaannya di masa covid-19, menimbulkan beberapa kendala dalam pembelajaran daring antara lain: ketersediaan kuota internet, jaringan yang tidak stabil, dan alat penunjang seperti gawai dan laptop (Rosali, 2020). Penelitian Cahyani et al., (2020) menemukan motivasi belajar pada siswa yang mengikuti pembelajaran daring atau online di tengah situasi pandemi virus Covid-19 ini menurun, karena nilai signifikansi yaitu 0,000 adalah kurang dari $0,05$ ( $\mathrm{p}<0,05)$ (Cahyani et al., 2020), dampak dari proses pembelajaran jarak jauh yang serba mendadak dan kurangnya kesiapan banyak menuai berbagai masalah dan kesenjangan negatif (Erni et al., 2020). Kondisi pembelajaran daring menyebabkan guru kesulitan untuk mempersiapkan bahan ajar atau materi ajar, kemampuan guru menyampaikan pembelajaran dan bagaimana guru menggunakan teknologi untuk membuat isi atau konten materi berbasis teknologi, masih ada beberapa guru yang harus mnenyesuaikan dirinya dengan teknologi pada saat pandemi yang dampaknya bisa mempengaruhi hasil belajar peserta didik.

Dampak Covid-19 ternyata memberikan ketidakpuasan dalam menerima materi pembelajaran. Alasan paling utama adalah karena selama ini mahasiswa memang menerima pembelajaran face-to-face, sehingga mungkin ada ketidaksiapan dalam menggunakan berbagai metode PJJ (Yilmaz, 2017). Dampak lainnya di pembelajaran guru sebagai bentuk TPACK; terjadi transformasi media pembelajaran berbasis teknologi melalui penggunaan WhatsApp grup, Zoom, Google Classroom, WebEx, You Tube, dan saluran TV (TVRI (Mansyur, 2020). Dari survei yang dilakukan ke 51 orang tua dari berbagai sekolah, dari sekolah dasar swasta, sekolah dasar negeri juga Madrasah Ibtidaiyah (MI), hasilnya menunjukkan semua menggunakan WhatsApp grup sebagai media komunikasi dalam belajar daring anak-anak mereka (Daheri et al., 2020), 
jenis media sosial yang popular yang memiliki presentasi tinggi adalah Whats App, facebook, Instagram dan YouTube. WhatsApp memiliki nilai presentasi tinggi 84,2\% dari pada jenis media social lainnya yang digunakan guru (Salehudin, 2020). Dalam penelitian Elianur pada guru PAI di Bengkulu menemukan bahwa media yang digunakan oleh guru di saat mengajar secara online adalah aplikasi WhatsApp dan zoom cloud; dan tanggapan guru terhadap pembelajaran secara daring mayoritas guru mengatakan bahwa pembelajaran secara daring tidak efektif (Elianur, 2020), walaupun dalam penelitian lain telah menemukan bahwa efektifitas penggunaan WhatsApp sebagai media pembelajaran mayoritas orang tua menyimpulkan tidak efektif yakni $41,2 \%$. 33,3 persen meragukan efektifitas WhatsApp ini. Hanya 25,5\% yang meyakini efektifitasnya (Daheri et al., 2020), mayoritas peserta didik lebih suka menggunakan aplikasi WA Grup ketika daring (Widiyono, 2020). Hasil penelitian menemukan bahwa penggunaan Aplikasi WhatsApp dalam pembelajaran daring mata pelajaran matematika di SDN Sumberagung 1 Kecamatan Ploso Klaten Kabupaten Kediri dalam kegiatan pembukaan, inti dan penutup, serta fitur yang sering digunakan adalah foto, video, link, Group WhatsApp, chat, dan voice note (Fauziah et al., 2021).

Diperkuat dengan hasil wawancara 85\% mengharapkan guru memberikan penjelasan yang memadai untuk tugas yang diberikan. Beberapa menyarankan melalui video call dan yang lainnya penjelasan melalui share video (Daheri et al., 2020), tingkat efektifitas pembelajaran sekitar 66,97\%, hal ini perlu ditingkatkan kembali agar pembelajaran lebih efektif guna peningkatan kualitas pembelajaran dan hasil belajar peserta didik (Hamdani \& Priatna, 2020). Sementara itu, menurut Dirjen Pendidikan Peserta Didik, Pendidikan Dasar, dan Pendidikan Menengah terdapat $60 \%$ guru yang kemampuannya dalam TIK masih terbatas. (merdeka.com, 15 April 2021) diakses pada 2021, Juli 2, serta terdapat kondisi guru di Indonesia tidak seluruhnya paham penggunaan teknologi, ini bisa dilihat dari guru-guru yang lahir tahun sebelum 1980-an, menjadi kendala teknologi informasi membatasi mereka dalam menggunakan media daring (Syah, 2020). Selain itu terdapat tiga unsur penting yang mendukung kesuksesannya, yaitu: peserta didik, guru, teknologi (Tîrziu \& Vrabie, 2015)

Peran guru sejatinya dituntut memberikan pengajaran yang baik, menciptakan suasana yang kondusif untuk belajar dan secara kreatif dan inovatif menggunakan media belajar yang menarik agar peserta didik dapat memahami materi pembelajaran dan tujuan pembelajaran dapat tercapai (Cahyani et al., 2020). Tantangan berat yang dihadapi dunia pendidikan di Indonesia dalam kompleks global adalah kemampuan guru dalam merancang pengembangan kompetensi guru yang di sebut TPACK atau Technological Pedagogical And Content Knowledge. TPACK merupakan integrasi pengetahuan dan keterampilan yang komprehensif dalam hal materi, pedagogi yang dipadukan dalam perkembangan teknologi. TPACK pertama kali dicetuskan oleh Schulman (1987) dan dikembangkan oleh Koehler \& Misra (2008).

TPACK dianggap sebagai kerangka kerja berpotensi yang dapat memberikan arah baru bagi guru dalam mengintegrasikan TIK kedalam kegiatan belajar mengajar di ruang kelas (Hewitt, 2008). Kerangka kerja teknologi, pedagogis, dan pengetahuan konten (TPACK) (Mishra \& Koehler, 2006) dikembangkan untuk menyoroti kebutuhan bahwa para guru memiliki pengetahuan dan keterampilan yang mencakup area TPACK yang berbeda ini. Mishra dan Koehler berpendapat bahwa semua jenis pengetahuan dan keterampilan instruksional ini harus diintegrasikan ketika menggunakan teknologi dalam pengajaran, kemudian guru harus mempertimbangkan bagaimana menyesuaikan instruksi yang diinformasikan TPACK dengan berbagai karakter yakni bisa berupa faktor peserta didik, seperti usia, preferensi, dan budaya.

Sesuai dengan penelitian Ajizah dan Huda (2020) menunjukkan bahwa TPACK memiliki peran yang sangat penting sebagai bekal guru dalam pembelajaran. TPACK merupakan kerangka pengetahuan yang terdiri dari Technology Knowledge, Pedagogy Knowledge, dan Content Knowledge. Dengan menguasai TPACK, guru dapat menyajikan pembelajaran yang inovatif dan kreatif, serta efektif di dalam kelas sehingga peserta didik dengan mudah memahami pembelajaran yang sedang berlangsung. Sehingga kemampuan guru terhadap TPACK menjadi solusi untuk mengimbangi karakteristik tersebut agar sesuai dengan tuntutan 
zamannya (Ajizah \& Huda, 2020), Integrasi teknologi dalam pembelajaran menjadi sebuah kebutuhan pendidikan. Apalagi saat ini sedang terjadi pandemi covid-19 dimana pembelajaran tidak lagi dilaksanakan di dalam kelas, tetapi dilaksanakan dari rumah masing-masing. Kegiatan pembelajaran lebih banyak dilaksanakan dari jarak jauh menggunakan media teknologi.

Untuk meningkatkan kegiatan pembelajaran, guru harus memiliki beberapa pengetahuan agar mengintegrasikan teknologi dalam pembelajaran dapat dilakukan guru secara maksimal. Pengetahuan tersebut disebut dengan TPACK (Technological Pedagogical Content Knowledge). TPACK merupakan kerangka teori dalam memahami pengetahuan guru terkait pengintegrasian materi pembelajaran, pengetahuan pedagogi, serta pengetahuan teknologi untuk menciptakan proses pembelajaran yang tepat dan efektif (Ajizah \& Huda, 2020). Melalui TPACK ini guru-guru akan mendukung sepenuhnya percepatan pembelajaran, mendukung semua penggunaan teknologi oleh guru dalam pembelajarannya, serta akan mendorong perbaikan hasil belajar peserta didik dalam upaya percepatan mewujudkan sumber daya manusia Indonesia yang unggul secara global.

Adapun pertanyaan kunci dalam penelitian ini adalah "Bagaimanakah Kemampuan TPACK Guru Sekolah Dasar dalam Melaksanakan Pembelajaran Daring di Masa Pandemi Covid19?" dengan tujuan penelitian adalah untuk mengurai tentang kemampuan TPACK Guru Sekolah Dasar dalam melaksanakan pembelajaran daring di masa pandemi covid-19 dengan tujuan penelitian adalah untuk: (1). Menganalisis pembelajaran daring dengan kemampuan pengetahuan teknologi (TK) guru Sekolah Dasar. (2). Menganalisis pembelajaran Daring dengan kemampuan pengetahuan pedagogik (PK) guru Sekolah Dasar (3). Menganalisis Pembelajaran Daring dengan kemampuan pengetahuan konten (CK) guru Sekolah Dasar.

\section{KAJIAN LITERATUR}

\section{Pembelajaran Daring di Masa Pandemi Covid-19}

Dampak Covid-19 bagi pendidikan sangat banyak bentuk dan sifatnya. Berbagai sisi memandang pengaruhnya secara positif ataupun negatif terhadap pendidikan, misalnya dampak positif dari virus corona yaitu untuk a) menghindari dari bahaya virus. b) mengirit biaya sekolah. c) menghemat waktu mempermudah mencari sesuatu dari internet. d) kebebasan belajar. e) lebih peka terhadap kebersihan dan orang tua mempunyai banyak waktu bersama anaknya, terdapat peran orang tua dalam menerapkan pembelajaran di rumah pada masa Covid19 (Cahyati \& Kusumah, 2020). Sisi negatif pendidikan pada masa Covid-19 yang meliputi a) kurangnya pemahaman materi oleh orang tua. b) kesulitan orang tua dalam menumbuhkan minat belajar anak. c) tidak memiliki cukup waktu untuk mendampingi anak karena harus bekerja. d) orang tua tidak sabar dalam mendampingi anak saat belajar dirumah. e) kesulitan orang tua dalam mengoperasikan gadget dan kendala terkait jangkauan layanan internet (Wardani \& Ayriza, 2020).

Kebijakan pembelajaran daring adalah keputusan Menteri Pendidikan bahwa pembelajaran dilakukan a) belajar dari rumah melalui pembelajaran daring/jarak jauh dilaksanakan untuk memberikan pengalaman belajar yang bermakna bagi peserta didik, tanpa terbebani tuntunan menuntaskan seluruh capaian kurikulum untuk kenaikan kelas atau kelulusan. b). belajar dari rumah dapat difokuskan pada pendidikan kecakapan hidup antara lain mengenai pandemic Covid-19. c). aktivitas dan tugas pembelajaran belajar dari rumah dapat bervariasi anatr peserta didik, sesuai minat dan kondisi masing-maasing, termasuk mempertimbangkan kesenjangan akses/fasilitas belajar di rumah. d). bukti atau produk aktivitas belajar dari rumah diberi umpan balik yang bersifat kualitatif dan berguna dari guru (Surat Edaran Nomor 4 Tahun 2020 Tentang Pelaksanaan Kebijakan Dalam Masa Darurat Penyebaran COVID-19, 2020).

\section{Pembelajaran Daring di Sekolah Dasar}

Pendidikan daring adalah merupakan bagian dari pendidikan jarak jauh. Pendidikan jarak jauh adalah pendidikan formal berbasis lembaga yang peserta didik dan instruktur atau 
gurunya berada di lokasi terpisah, sehingga memerlukan sistem telekomunikasi interaktif untuk menghubungkan keduanya dan berbagai sumber daya yang diperlukan di dalamnya. Pembelajaran elektronik (e-learning) (Suartama et al., 2020) atau pembelajaran daring (online) merupakan bagian dari pendidikan jarak jauh yang secara khusus menggabungkan teknologi elektronika dan teknologi berbasis internet. Pendidikan jarak jauh bukan metode baru dalam sistem pendidikan. Metode pembelajaran ini telah digunakan di Amerika Serikat sejak tahun 1892 ketika Universitas Chicago meluncurkan program pembelajaran jarak jauh pertamanya untuk tingkat pendidikan tinggi. Metode pembelajaran jarak jauh terus berkembang dengan menggunakan beragam teknologi komunikasi dan informasi termasuk radio, televisi, satelit dan internet.

Sistem pembelajaran daring merupakan sistem pembelajaran tanpa tatap muka secara langsung antara peserta didik dan pendidik, melainkan secara online yang menggunakan jaringan internet". Menurut Thome (2003) "pembelajaran daring adalah pembelajaran yang dalam proses pembelajarannya menggunakan teknologi multimedia, kelas virtual, video, teks animasi online, email, pesan suara, telepon konferensi dan video streaming online" (Kuntarto, 2017:101). Sejalan dengan pendapat Moore dkk (2011) mengatakan "pembelajaran daring adalah pembelajaran yang mengandalkan konektivitas, fleksibilitas, dan interaksi secara daring. Pembelajaran daring diyakini saling berkaitan dengan konteks definisi pembelajaran jarak jauh atas kesamaan karakteristik yang dimiliki keduanya, dimana pembelajaran daring merupakan implementasi dari praktik pembelajaran jarak jauh yang membutuhkan konektivitas dan aksesibiltas". Menurut Enriquez (2014)“ dalam pembelajaran daring guru dan peserta didik melakukan pembelajaran di waktu yang sama dengan menggunakan aplikasi seperti WhatsApp, Edmodo, Telegram, Zoom Meeting, Google Meet, Google Classroom, Ruang Guru dan aplikasi lainnya.

Dalam pembelajaran daring, kita mengenal ada istilah pembelajaran daring sinkron dan pembelajaran daring asinkron. Menurut Chaeruman (2017) dalam pembelajaran sinkron peserta didik dan guru berada pada tempat dan waktu yang sama. Pembelajaran ini mirip dengan kelas tatap muka. Contohnya adalah pada saat guru dan peserta didik berpartisipasi dalam kelas melalui web conference. Ini yang disebut sebagai kelas virtual. Pada kelas ini memungkinkan peserta didik untuk mengajukan pertanyaan dan guru menjawab secara langsung. Sedangkan pembelajaran asinkron adalah pendekatan pembelajaran mandiri dengan interaksi asinkron untuk mendorong pembelajaran. WhatsApp, email, Wikipedia, blog adalah sumber daya yang mendukung pembelajaran asinkron. Perbedaan antara pembelajaran sinkron dan asinkronus adalah bahwa pembelajaran sinkron melibatkan sekelompok peserta didik yang terlibat dalam pembelajaran pada saat yang sama mirip dengan kelas virtual sedangkan pembelajaran asinkron melibatkan pembelajaran yang berpusat pada peserta didik mirip dengan pendekatan belajar mandiri dengan sumber online yang diperlukan.

Masa Pandemi Covid-19 adalah memanfaatkan teknologi dan media sosial pada pembelajaran daring peserta didik di rumah, menjalin kerja sama yang baik dengan orang tua melalui group WhatsApp selama pembelajaran daring di rumah (Mastur et al., 2020; Salehudin, 2020), berikut beberapa peran guru adalah sebagai berikut: Guru sebagai pendidik guru adalah panutan dan teladan bagi masyarakat harus punya sifat, Guru sebagai pengajar yaitu guru membuka pelajaran dan menutup pelajaran, keterampilan bertanya, Guru sebagai konselor (pembimbing) tugasnya mengatasi peserta didik peserta didik itu beragam masalah akademik maupun non akademik. Guru berbagai pelatih, pelatih dengan kata dasar latihan artinya pembiasaan (dibiasakan), (terbiasa), (kebiasaan). Guru sebagai penasehat, pahami dan keunikan anak-anak yang mempunyai masalah pastinya nasihat yang berbeda, mendengarkan keluhan anak, guru sabar mendengarkan, beri kepercayaan dan ruang pertimbangan untuk menasihati anak secara bertahap. Pihak terkait perlu juga mengevaluasi pembelajaran daring agar semua tujuan pembelajaran dapat tercapai dengan optimal. Beban belajar peserta didik sebagai pertimbangan dan diperhitungkan dengan maksimal, terukur baik secara materi maupun waktu. Yang perlu diperhatikan adalah bahwa guru tidak diperbolehkan semata-mata memberikan 
tugas-tugas, tapi harus memberikannya secara matang, sehingga guru dapat memberikan apresiasi capaian peserta didik (Wahyono et al., 2020).

Teori konstruktivisme menjadi bahan dan pertimbangan dalam menciptakan materi pembelajaran daring juga harus diperhatikan yang menjadikan Peserta didik berperan aktif. Materi daring harus dapat disajikan bukanlah materi yang kompleks atau materi yang utuh, namun dapat dalam bentuk materi-materi yang dapat merangsang atau memberikan stimulus untuk menjembatani peserta didik menyusun sebuah simpulan dari kompetensi yang akan dikuasai. Tokoh konstruktivisme adalah Jean Piaget ia dikenal sebagai seorang psikolog pada akhirnya dia lebih tertarik pada filsafat konstruktivistik dalam proses belajar. Jean Piaget membuat teorinya yang menjadi dasar pada aliran konstruktivistik adalah perkembangan fikiran secara alami dari lahir sampai dewasa. Menurutnya untuk dapat memahami teori ini harus paham tentang asumsi-asumsi biologi maupun implikasi asumsi-asumsi tersebut dalam mengartikan pengetahuan.

\section{Tecnological Pedagogical And Content Knowledege (TPACK)}

Perpaduan antara pengetahuan teknologi, pedagogi, dan konten yang harus dikuasai oleh guru saat ini sering disebut dengan Technological Pedagogical and Content Knowledge (TPACK) yang merupakan sebuah kerangka konseptual gabungan dari pengetahuan teknologi, pedagogi, dan konten yang saling berhubungan (Koehler et al., 2009). TPACK adalah pusat pembelajaran yang terdiri dari tiga komponen yaitu: pengetahuan teknologi (TK), pengetahuan pedagogis (PK) dan pengetahuan konten (CK) (Mishra \& Koehler, 2014). Interaksi dari ketiga bentuk pengetahuan tersebut akan mengembangkan bentuk pengetahuan sekunder yang mencakup pengetahuan konten pedagogis (PCK), pengetahuan pedagogis teknologi (TPK), pengetahuan konten teknologi (TCK) dan akhirnya sintesis dari ketiga bentuk pengetahuan sekunder tersebut maka akan terbentuk TPACK.

Technological Knowledge (TK). Technological Knowledge meliputi pemahaman bagaimana menggunakan software dan hardware komputer, peralatan presentasi seperti dokumen presentasi, dan teknologi lainnya dalam konteks pendidikan. Technological Knowledge juga meliputi kemampuan untuk mengadaptasi dan mempelajari teknologi baru (Quddus, 2020). Content Knowledge mengarah kepada pengetahuan atau kekhususan disiplin ilmu atau materi pelajaran. Content Knowledge ini berbeda di tiap tingkatannya (contoh perbedaan di sekolah dasar dan sekolah menengah). Seorang guru diharapkan menguasai kemampuan ini untuk mengajar. Content Knowledge juga penting karena kemampuan tersebut menentukan cara kekhasan berpikir dari disiplin ilmu tertentu pada setiap kajiannya.

Survei TPACK terhadap minat menggunakan kerangka TPACK dan survei TPACK untuk merancang dan menilai pengetahuan guru dalam berbagai konteks pendidikan guru merupakan indikasi yang jelas dari dampak TPACK di seluruh dunia sebagai alat penelitian dan pengembangan yang muncul untuk pendidik guru (Baran et al., 2011). TPACK dianggap sebagai arah baru bagi guru dalam memecahkan masalah terkait dengan mengintegrasikan TIK ke dalam proses pembelajaran di ruang kelas. Pada perkembangannya, TPACK telah menjadi kerangka kerja atau framework yang dapat digunakan untuk menganalisis pengetahuan guru terkait dengan integrasi teknologi dalam pembelajaran. Ada 3 komponen utama dari pengetahuan guru: materi, pedagogi, dan teknologi. (Koehler \& Mishra, 2009: 62). Berikut ini gambaran framework. 


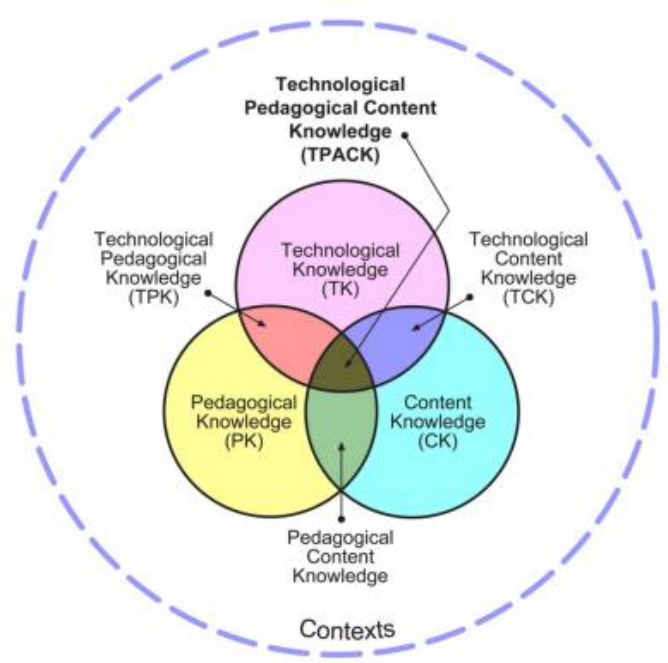

Gambar 1. framework Tecnological Pedagogical And Content Knowledege (TPACK)

\section{Keunggulan dan Manfaat TPACK dalam Pembelajaran}

Guru dalam pembelajaran abad 21 diharapkan dapat menguasai pengetahuan teknologi, pedagogi, dan konten dalam menyampaikan pembelajaran. peranan teknologi sangatlah penting bagi guru dalam meningkatkan kualitas pembelajaran melalui TPACK sehingga guru diharuskan memiliki literasi TIK yang baik (Prasetyo et al., 2019).

TPACK adalah pusat pembelajaran yang terdiri dari tiga komponen (Baran et al., 2011) yaitu: pengetahuan teknologi (TK), pengetahuan pedagogis (PK) dan pengetahuan konten (CK) (Koehler et al., 2013). interaksi dari ketiga bentuk pengetahuan tersebut akan mengembangkan bentuk pengetahuan sekunder yang mencakup pengetahuan konten pedagogis (PCK), pengetahuan pedagogis teknologi (TPK), pengetahuan konten teknologi (TCK) dan akhirnya sintesis dari ketiga bentuk pengetahuan sekunder tersebut akan terbentuk .

TPACK terdiri dari PCK adalah bentuk unik dari pengetahuan guru yang mensintesis PK dan CK guru untuk membantu peserta didik dalam menjembatani kesulitan penguasaan materi pelajaran (Shulman, 1986). Sejalan dengan itu, TPK adalah bentuk PK unik yang dikaitkan dengan penggunaan jenis teknologi tertentu sedangkan TCK mengacu pada pengetahuan konten yang diwakili secara teknologi yang tidak dibuat untuk tujuan pengajaran. Akhirnya, TPACK merujuk pada bentuk terintegrasi pengetahuan yang dapat diciptakan melalui kombinasi yang berbeda dari enam bentuk pengetahuan yang dibahas sebelumnya (Cox \& Graham, 2009).

Menurut Shulman dalam Fox (2011) menyebut bahwa Kerangka kerja mereka mengidentifikasi empat jenis tambahan pengetahuan guru (teknologi pengetahuan (TK), pengetahuan konten teknologi (TCK), pengetahuan teknologi-pedagogis (TPK) dan pengetahuan konten teknologi-pedagogis (TPCK) yang dibutuhkan oleh guru untuk berhasil mengintegrasikan penggunaan teknologi digital dalam pengajaran mereka Ini datang di atas (pengetahuan pedagogis (PK), pengetahuan konten (CK) dan pengetahuan konten pedagogis (PCK)) (Fox, 2011). Perspektif konstruktivistik memberi penekanan pada membangun jaringan komunikasi kolaboratif dengan memanfaatkan media sosia; baik secara asinkronus maupun sinkronus, menyediakan tempat dan ruang secara virtual untuk memanfaatkan teknologi mutakhir mengkonstruksi makna berdasarkan pengalaman (S. Sirate \& Yaumi, 2017). Secara umum, kerangka TPACK dapat memberikan kejelasan pada intervensi khusus dalam proyek penelitian dan pengembangan dan dengan demikian meningkatkan kemampuan untuk merancang dan menguji pendekatan teknologi yang kuat (Baran et al., 2011).

\section{METODE PENELITIAN}

Pendekatan yang digunakan dalam penelitian ini adalah pendekatan kualitatif dengan jenis penelitian fenomenologi, hal ini di dapat dari sebuah fenomena yang terjadi di lingkungan 
sekitar yang membahas kemampuan TPACK pada guru sekolah dasar dalam melaksanakan pembelajaran daring pada di masa pandemi covid-19. Penelitian ini dilakukan Sekolah Dasar Negeri 006 Sangkulirang Desa Benua Baru Ilir Kecamatan Sangkulirang Kabupaten Kutai Timur Propinsi Kalimantan Timur. Teknik pengumpulan data yang digunakan dalam penelitian ini adalah dengan observasi, wawancara dan dokumentasi (Sugiono, 2010). Pengumpulan data dengan menetapkan informan penelitian ini adalah para guru yang memiliki kualifikasi guru yang menerapkan TPACK, dilakukan pula observasi secara langsung, serta wawancara mendalam dan tinjauan dokumen sebagai data sekunder.

Proses wawancara dalam penelitian ini dilakukan dengan menggunakan teknik wawancara terstruktur, dilanjutkan dengan mempersiapkan pedoman wawancara, alat bantu wawancara dengan buku catatan, rekaman audio dan atau kamera smartphone. Teknik analisis data digunakan dengan model miles Huberman, Menurut Miles dan Huberman (Miles and Huberman, 2014; Suwendra, 2018) di dalam analisis data kualitatif terdapat tiga tahapan kegiatan, yaitu data condensation, data display dan conclusion / verifications.

\section{HASIL DAN PEMBAHASAN}

SDN 006 Sangkulirang terletak di Jalan Patimura RT XVII, Desa Benua Baru Ilir Kecamatan Sangkulirang. Sekolah ini berdiri sejak tahun 1971 dengan nama awal SDN 045 kemudian berubah menjadi SDN 009 dan kini berubah nama menjadi SDN 006 Sangkulirang. SDN 006 Sangkulirang didirikan di atas lahan seluas $4.015 \mathrm{~m}^{2}$ dengan luas bangunan $902,5 \mathrm{~m}^{2}$, Hasil penelitian yang kami lakukan dalam penelitian ini

\section{HASIL}

\section{Pembelajaran daring dengan kemampuan pengetahuan teknologi (TK) guru Sekolah Dasar}

Dalam pelaksanaan daring banyak sekali opsi yang dapat dipilih oleh masing-masing pendidik atau guru sehingga untuk memaksimalkan pembelajaran pemilihan fasilitas yang tepat, mudah dan murah dapat dilakukan agar tidak memberatkan orang tua, guru atau manajemen lainnya sehingga aplikasi yang akan dipakai dapat maksimal digunakan pada pembelajaran. Penggunaan teknologi yang penting juga adalah kemampuan pengetahuan teknologi yang dimiliki oleh guru sekolah dasar, guru harus memahami bahwa teknologi pembelajaran merupakan teknologi yang digunakan dalam pembelajaran yang dilihat sebagai teknologi peralatan yang berkaitan dengan penggunaan peralatan media dan sarana untuk mencapai tujuan pendidikan atau dalam skala kecil adalah kegiatan tujuan pembelajaran, yakni dengan memanfaatkan alat-alat teknologi yang disediakan untuk pembelajaran.

Hasil wawancara menemukan bahwa guru menggunakan teknologi sesuai dengan kemampuan dan pengetahuan guru, wawancara pada guru menemukan:

"Teknologi yang saya gunakan dalam melaksanakan pembelajaran daring adalah yang saya kuasai diantaranya WhatsApp, Google Meet, zoom meeting. WhatsApp saya gunakan di semua kelas dari kelas 1 hingga kelas 6. Zoom meeting dan google meet saya gunakan untuk mengajarkan praktik gerakan". (wawancara: Bapak Ardiansyah, 20 September 2021/jam 11.00).

Dari hasil wawancara di atas, maka dapat diketahui bahwa guru menggunakan aplikasi teknologi seperti google meet, Google Classroom, aplikasi zoom meeting dan ataupun media sosial WhatsApp yang semuanya yang dipahami dan mudah dalam menggunakan jaringan internet kecil, internet yang bisa digunakan lebih hemat atau internet yang lebih besar menggunakan jaringan wi-fi atau jaringan yang disediakan oleh fasilitas penyedia internet.

Hasil wawancara kepada guru sekolah dasar didapatkan bahwa guru menggunakan lebih banyak menggunakan WhatsApp sesuai dengan keadaan dan kemampuan dan fasilitas yang tersedia. Pembelajaran menggunakan jaringan atau pembelajaran daring sangat penting dibuat dengan sistem pembelajaran tatap muka secara langsung online dengan menggunakan jaringan internet, guru dan peserta didik melakukan pembelajaran bersama, waktu yang sama dengan menggunakan berbagai aplikasi seperti WhatsApp, zoom meeting, Google Meet, dalam fasilitas 
pembelajaran tersebut. Dalam pembelajaran daring internet memegang peran penting yang semuanya membutuhkan biaya untuk memiliki hubungan fasilitas jarak jauh.

Guru dapat memanfaatkan teknologi yang ada agar terjadi proses interaksi antara guru dengan peserta didik, diantaranya guru dan peserta didik bisa bertanya atau berdiskusi dengan guru atau teman-temannya. Guru dapat memberi tugas dan membagikan materi atau bahan ajar dengan mudah dan lebih cepat, siswa dapat mengumpulkan tugasnya dengan cepat, siswa dapat menanyakan pekerjaan atau lembar kerja peserta didik dengan lebih jelas dan praktis atau lebih efektif, akan terlihat manfaat dan keunggulan dari teknologi tersebut.

Menurut saya, suatu teknologi itu bermanfaat ketika siswa dapat menggunakannya dalam mengerjakan tugas-tugas yang diberikan, kemudian siswa juga kadang menanyakan hal-hal yang mereka tidak ketahui atau belum jelas. Saya menggunakan teknologi untuk mendownload materi dan video Youtube dan digunakan pada WhatsApp atau zoom, dengan materi ini siswa bisa menanyakan tugas-tugas di group yang sudah saya buat sehingga siswa dapat cepat mengerjakan dan mengumpulkan tugas-tugasnya. Sehingga saya pun dapat mengetahui apakah siswa-siswa telah mengerjakan tugasnya atau belum (wawancara: Ibu Marlinda Puspitawati, selasa, 21 September 2021/ jam 09.00 wita).

Dari hasil wawancara pada penelitian ini kami dapatkan bahwa guru-guru menggunakan internet yang disediakan oleh sekolah ataupun menggunakan jaringan internet di rumah, hasil wawancara sebagai berikut:

Saya hanya menggunakan internet di sekolah karena ada jaringan yang disediakan oleh sekolah, tapi kalau di rumah saya menggunakan paket data karena belum tersedia jaringan internet yang ada di rumah saya. Internet ini sangat penting dalam pembelajaran daring, apalagi jika ada kendala dalam jaringan internet maka terjadi pula kendala dalam pembelajaran saya (wawancara: Ibu Mardiana, selasa, 21 September 2021/ jam 09.00 wita)..

Keterbatasan guru dalam melakukan kontrol terhadap kegiatan pembelajaran dapat dilakukan dengan cara membuat pesan pengisian daftar hadir, kemudian guru dapat mengeceknya kehadiran siswa atau menggunakan aplikasi Google form, sehingga kendalakendala dalam mengecek kehadiran bisa diatasi, demikian pula jika kendala dalam melihat pekerjaan siswa maka guru bisa melakukan telepon atau video call / video conference, dengan video langsung ini guru dapat mengetahui ekspresi dan sikap siswa dalam mengerjakan tugastugas yang telah diberikan guru.

Selama pembelajaran daring banyak masalah yang saya temui. Antara lain kebanyakan siswa tidak mempunyai hand phone, dan untuk mengikuti kegiatan pembelajaran menggunakan HP orang tua. Jadi untuk mengatasi permasalahan yang ditimbulkan dalam pembelajaran saya membuat grup WA kelas, saya membuka kelas setiap hari, mengecek kehadiran siswa setiap hari, dan mengirimkan tugas-tugas melalui grup tersebut. (wawancara: Ibu Siti Hadrah, kamis, 23 September 2021/ jam 09.00 wita).

Dapat di tarik kesimpulan bahwa guru menemukan banyak kendala-kendala dalam pembelajaran daring, meliputi kepemilikan saran belajar seperti handphone dan laptop, keterbatasan internet dan mengumpulkan tugas-tugas. Juga guru memanfaatkan teknologi sebagai bahan ajar dan berjalannya pembelajaran, dimana guru dapat berkomunikasi dan berinteraksi belajar, juga dapat menyelesaikan tugas-tugas belajar siswa dengan baik dan cepat

\section{Pembelajaran Daring dengan kemampuan pengetahuan pedagogik (PK) guru Sekolah Dasar.}

Pada bagian yang hubungan dengan kemampuan pengetahuan pedagogik atau pedagogical knowledge bagi guru sekolah dasar hal ini menjadi penting karena pedagogical ini mengacu pada kemampuan guru untuk menggunakan metode atau proses pembelajaran secara umum, yang mencakup bagian-bagian yang memiliki hubungan dengan perencanaan, pelaksanaan, pengembangan dan evaluasi. Dalam bagian pedagogical knowledge atau pengetahuan tentang 
berbagai teknologi yang dapat digunakan dalam aktivitas pengajaran dan pemahaman bahwa penggunaan teknologi dapat mengubah cara guru mengajar atau menyampaikan pembelajaran termasuk kemampuan dan keterbatasan pedagogis dari berbagai alat teknologi yang digunakan selanjutnya dalam bagian pedagogical.

Selama pandemi ini guru-guru di minta membuat kurikulum sederhana atau RPP satu lembar untuk menyesuaikan dengan kondisi saat ini. (wawancara: Ibu Siti Hadrah, kamis, 23 September 2021/jam 09.00 wita).

\section{Pembelajaran Daring dengan kemampuan pengetahuan konten (CK) guru Sekolah Dasar}

Keberhasilan sebuah pembelajaran tergantung kepada ketercapaian tujuan kompetensi belajar peserta didik yang meliputi adanya kompetensi kognitif kompetensi afektif dan kompetensi motor serta perwujudan dari penerapan nilai-nilai baik dalam berfikir maupun bertindak memastikan seluruh peserta didikmemiliki penguasaan kompetensi dalam suatu materi ajar yang kemudian melanjutkan ke materi-materi pelajaran berikutnya adalah merupakan maksud dari sebuah aktivitas yang disebut dengan ketuntasan belajar. Ketuntasan belajar ini merujuk kepada kompetensi-kompetensi yang dicapai serta ditunjang dengan indikator guna mengukur tingkat ke tercapainya semua aspek ketuntasan belajar ini hanya dapat dicapai dengan kolaborasi dan kerja sama antara kedua belah pihak yaitu oleh guru dan juga peserta didik. Dalam pembelajaran di masa Covid-19 penerapan pembelajaran menggunakan daring di mana kurangnya akses teknologi atau akses internet yang cepat dan handal. maka dirasakan oleh peserta didik di beberapa tempat dan ada juga keluarga yang kurang beruntung maka untuk mereka melakukan kegiatan belajar terutama bagi peserta didik dari keluarga kurang mampu cara untuk mengatasi atau mengurangi risiko, maka penerapan program belajar daring bagi peserta didik yang tidak internet menjadi kesulitan tersendiri bagi mereka untuk mengikuti pembelajaran daring.

Hasil wawancara menemukan bahwa ada saja guru di saat covid-19 ini tidak melakukan pengembangan pembelajaran yang luas, hanya mengambil dari buku guru dan buku peserta didik, sebagai berikut:

Untuk menyusun materi ajar atau bahan ajar selama masa pandemi ini saya tidak mengembangkan materi ajar dari bahan-bahan atau sumber yang lainnya tapi hanya dari buku pegangan guru dan juga materi sesuai dengan buku pegangan siswa yang ada dicetak oleh Kementerian. (wawancara: Ibu Mardiana, kamis, 23 September 2021/ jam 11.00 wita).

Materi pembelajaran di pilih secara optimal mungkin untuk membantu peserta didik dalam mencapai standar kompetensi lulusan dan kompetensi dasar, ada beberapa hal yang perlu diperhatikan yang berkenaan dengan pemilihan materi pembelajaran, yakni adalah jenis materi cakupan dari materi itu sendiri, urutan-urutan dalam materi yang dibuat harus dengan perlakuan atau kegiatan treatment terhadap materi pembelajaran yang dibuat guru tersebut.

Guru sekolah dasar khususnya di kelas-kelas rendah, dituntut harus lebih kreatif dalam menginovasikan peralatan TIK sesuai dengan karakteristik siswa atau peserta didik, di kelas tersebut pemanfaatan teknologi juga menyesuaikan dengan karakteristik setiap mata pelajaran yang berbeda-beda. Guru kelas dapat memegang peran penting dalam kegiatan pemanfaatan teknologi, sehingga seorang guru harus menjadi untuk langsung dalam pemanfaatan teknologi sebagai peralatan pembelajaran di sekolah dasar, untuk sumber belajar guru dapat memanfaatkan sumber belajar yang ada di lingkungannya, memanfaatkan sumber belajar teknologi yang bersumber dari TIK, internet dan website yang dapat digunakan untuk mendukung semua aktivitas belajar peserta didik. Agar peserta didik mampu mengarahkan aktivitasnya dalam belajar dan memenuhi standar kompetensi lulusan termasuk kompetensi dasar dalam setiap pembelajaran.

Sebagaimana gambaran hasil penelitian di atas, maka secara singkat seluruh hasil penelitian dapat dilihat dalam tabel berikut: 
Tabel 1. Display data hasil penelitian

\begin{tabular}{|c|c|c|}
\hline No & Temuan / Hasil Penelitian & $\begin{array}{l}\text { Bidang } \\
\text { temuan }\end{array}$ \\
\hline 1 & Menggunakan WhatsApp dan zoom meeting & TK \\
\hline 2 & $\begin{array}{l}\text { Mendownload materi melalui wesite / internet dan materi } \\
\text { dari Youtube }\end{array}$ & TK \\
\hline 3 & Guru membagikan link (share) melalui WA atau Zoom & TK \\
\hline 4 & Memanfaatkan internet dalam pembelajaran & TK \\
\hline 5 & Guru dapat berkomunikasi / interaksi belajar & TK \\
\hline 6 & $\begin{array}{l}\text { Guru mengarahkan peserta didik mampu mengerjakan } \\
\text { tugas-tugas pembelajaran }\end{array}$ & TK \\
\hline 7 & Menggunakan Kurikulum darurat & PK \\
\hline 8 & Guru mampu merancang perangkat pembelajaran & PK \\
\hline 9 & Menggunakan media pembelajaran yang menarik & PK \\
\hline 10 & $\begin{array}{l}\text { Guru menyesuaikan karakter dengan metode yang } \\
\text { digunakan }\end{array}$ & PK \\
\hline 11 & Guru melakukan evaluasi pembelajaran & PK \\
\hline 12 & Guru mampu menyusun materi atau bahan ajar & CK \\
\hline 13 & Guru menggunakan sumber belajar berbasis teknologi & Ck \\
\hline
\end{tabular}

\section{PEMBAHASAN}

Terdapat beberapa temuan sebagai hasil penelitian yang berbasis pengetahuan tentang bahan ajar atau materi sebagai pengetahuan teknologi sebagai berikut; guru menggunakan WhatsApp dan zoom meeting sebagai LMS, guru mendownload materi melalui website /internet dan materi dari Youtube dan Guru membagikan link (share) melalui WA atau Zoom, guru memanfaatkan internet dalam pembelajaran, Guru dapat berkomunikasi / interaksi belajar serta Guru mampu mengarahkan peserta didik mengerjakan tugas-tugas pembelajaran.

Prinsip-prinsip berorientasi pada peserta didik, berarti bahwa adanya usaha-usaha pendidikan pembelajaran ataupun pelatihan hendaknya memusatkan perhatiannya pada peserta didik kemudian memperhatikan prinsip pemanfaatan sumber belajar semaksimal dan bervariasi mungkin, khususnya sumber belajar yang berupa peralatan teknologi atau sumber belajar menggunakan teknologi untuk peserta didik belajar karena interaksi dengan berbagai sumber belajar secara maksimal dan bervariasi akan memberi manfaat aneka sumber belajar siswa lebih bervariasi.

Guru dapat menggunakan yang biasanya disediakan gratis seperti group Google yakni Google classroom (Abazi-Bexheti et al., 2018) yang memiliki berbagai fitur fasilitas dan memiliki bagian yang menyimpan data, menilai dan membuat materi atau bahan ajar, itu pun dapat diakses dan digunakan oleh guru secara gratis dan kapan pun sedangkan LMS lainnya perlu dipelajari oleh guru-guru sehingga mereka akan mampu menggunakannya dengan lebih baik seperti aplikasi LMS Moodle, Edmodo dan Schology dan sebagainya (Ak et al., 2018). Bentuk umum pengetahuan ini berlaku untuk memahami bagaimana siswa belajar, keterampilan umum manajemen kelas, perencanaan pelajaran, dan penilaian siswa. Ini mencakup pengetahuan tentang teknik atau metode yang digunakan di kelas; sifat audiens sasaran; dan strategi untuk mengevaluasi pemahaman siswa (Baran et al., 2011; Rahmadi, 2019). Seorang guru dengan pengetahuan pedagogis yang mendalam memahami bagaimana siswa membangun pengetahuan dan memperoleh keterampilan dan bagaimana mereka mengembangkan kebiasaan pikiran dan disposisi positif terhadap pembelajaran. Dengan demikian, pengetahuan pedagogis membutuhkan pemahaman teori kognitif, sosial, dan perkembangan belajar dan bagaimana mereka berlaku untuk siswa di kelas (Anderson \& Krathwohl, 2015).

PCK konsisten dengan dan mirip dengan gagasan Shulman tentang pengetahuan pedagogi yang berlaku untuk pengajaran konten tertentu. Inti dari konseptualisasi Shulman tentang PCK adalah gagasan tentang transformasi materi pelajaran untuk 
pengajaran. Secara khusus, menurut Shulman dalam artikel (Koehler et al., 2009), transformasi ini terjadi ketika guru menafsirkan materi pelajaran, menemukan berbagai cara untuk mewakilinya, dan menyesuaikan dan menyesuaikan bahan ajar dengan konsepsi alternatif dan pengetahuan siswa sebelumnya. PCK mencakup bisnis inti pengajaran, pembelajaran, kurikulum, penilaian dan pelaporan, seperti kondisi yang mendorong pembelajaran dan hubungan antara kurikulum, penilaian, dan pedagogi. Kesadaran akan kesalahpahaman umum dan cara memandangnya, pentingnya menjalin hubungan di antara ide-ide berbasis konten yang berbeda, pengetahuan awal siswa, strategi pengajaran alternatif, dan fleksibilitas yang berasal dari mengeksplorasi caracara alternatif untuk melihat ide atau masalah yang sama semuanya penting untuk pengajaran yang efektif.

Menghormati gagasan bahwa mengajar dengan teknologi adalah tugas yang kompleks dan tidak terstruktur, kami mengusulkan bahwa pendekatan pemahaman untuk integrasi teknologi yang sukses membutuhkan pendidik untuk mengembangkan cara baru untuk memahami dan mengakomodasi kompleksitas ini (Harde \& Borkar, 2020). Inti dari pengajaran yang baik dengan teknologi adalah tiga komponen inti: konten, pedagogi, dan teknologi, ditambah hubungan di antara dan di antara mereka. Interaksi antara dan di antara tiga komponen, bermain secara berbeda di berbagai konteks, menjelaskan variasi luas yang terlihat dalam tingkat dan kualitas integrasi teknologi pendidikan. Ketiga basis pengetahuan ini (konten, pedagogi, dan teknologi) membentuk inti dari kerangka kerja teknologi, pedagogi, dan pengetahuan konten (TPACK). Ikhtisar kerangka kerja disediakan di bagian berikut, meskipun deskripsi yang lebih rinci dapat ditemukan di tempat lain (Koehler et al., 2009; Koehler \& 2008;). Perspektif ini konsisten dengan peneliti lain dan pendekatan yang telah berusaha untuk memperluas gagasan Shulman tentang pengetahuan konten pedagogis (PCK) untuk memasukkan teknologi pendidikan.

Dapat ditarik kesimpulan adalah kemampuan pengetahuan pedagogik (PK) guru sekolah dasar pembelajaran daring adalah sudah baik dan tepat, karena guru sudah mampu merancang perangkat pembelajaran yang tepat, guru pun sudah menggunakan media pembelajaran yang menarik, guru mampu menyesuaikan karakter peserta didik dengan metode yang digunakan dalam pembelajaran serta guru mampu melakukan evaluasi pembelajaran (Salehudin et al., 2020).

Sebagai Content knowledge (CK) adalah pengetahuan guru tentang materi pelajaran yang akan dipelajari atau diajarkan kepada peserta didik. Konten yang akan dibahas dalam sains atau sejarah sekolah menengah berbeda dengan konten yang akan dibahas dalam materi sosial seperti tentang apresiasi seni atau seminar pascasarjana tentang astrofisika. Pengetahuan tentang konten sangat penting bagi guru. Sebagaimana yang disampaikan oleh Shulman dalam artikel (Koehler et al., 2009) mencatat, pengetahuan ini akan mencakup pengetahuan tentang konsep, teori, ide, kerangka organisasi, pengetahuan tentang bukti dan bukti, serta praktik dan pendekatan yang mapan untuk mengembangkan pengetahuan tersebut. Pengetahuan dan sifat inkuiri sangat berbeda antar bidang, dan guru harus memahami dasar-dasar pengetahuan yang lebih dalam dari disiplin ilmu di mana mereka mengajar. Dalam kasus sains, misalnya, ini akan mencakup pengetahuan tentang fakta dan teori ilmiah, metode ilmiah, dan penalaran berbasis bukti. Dalam hal apresiasi seni, pengetahuan tersebut akan mencakup pengetahuan tentang sejarah seni, lukisan terkenal, patung, seniman dan konteks sejarahnya, serta pengetahuan tentang teori estetika dan psikologi untuk mengevaluasi seni (Graham et al., 2012).

Pengetahuan konten yang komprehensif dapat menjadi penghalang; misalnya, siswa dapat menerima informasi yang salah dan mengembangkan kesalahpahaman tentang area konten. Namun pengetahuan konten, dalam dan dari dirinya sendiri, adalah domain yang tidak 
terstruktur, dan sebagai perang budaya (Zimmerman, 2010), kontroversi Great Books (Anderson \& Krathwohl, 2015), dan pertempuran pengadilan atas pengajaran evolusi menunjukkan, isu-isu yang berkaitan dengan isi kurikulum dapat menjadi area pertentangan dan ketidaksepakatan yang signifikan. Pilihan teknologi memberi dan membatasi jenis ide konten yang dapat diajarkan. Demikian juga, keputusan konten tertentu dapat membatasi jenis teknologi yang dapat digunakan. Teknologi dapat membatasi jenis representasi yang mungkin, tetapi juga mampu membangun representasi yang lebih baru dan lebih bervariasi. Selain itu, alat teknologi dapat memberikan tingkat fleksibilitas yang lebih besar dalam menavigasi seluruh representasi ini (Prasetyo et al., 2019).

TCK adalah pemahaman tentang cara teknologi dan konten saling memengaruhi dan membatasi. Guru perlu menguasai lebih dari materi pelajaran yang mereka ajarkan; mereka juga harus memiliki pemahaman yang mendalam tentang cara di mana materi pelajaran (atau jenis representasi yang dapat dibangun) dapat diubah dengan penerapan teknologi tertentu. Guru perlu memahami teknologi spesifik mana yang paling cocok untuk menangani pembelajaran materi pelajaran di domain mereka dan bagaimana konten mendikte atau bahkan mungkin mengubah teknologi atau sebaliknya. Sebagai masalah praktis yang signifikan, sebagian besar teknologi yang dipertimbangkan dalam literatur saat ini lebih baru dan digital dan memiliki beberapa sifat bawaan yang membuat penerapannya dengan cara yang mudah menjadi sulit (Srisawasdi, 2012). Sistem pembelajaran dilaksanakan melalui perangkat personal computer (PC) atau laptop yang terhubung dengan koneksi jaringan internet. Guru dapat melakukan pembelajaran bersama di waktu yang sama menggunakan grup di media sosial seperti WhatsApp (WA) (Fauziah et al., 2021; Salehudin, 2020), telegram, instagram, aplikasi zoom ataupun media lainnya sebagai media pembelajaran (Brahma, 2020).

Dengan demikian, guru dapat memastikan peserta didik mengikuti pembelajaran dalam waktu bersamaan, meskipun di tempat yang berbeda. Guru pun dapat memberi tugas terukur sesuai dengan tujuan materi yang disampaikan kepada peserta didik. Tetapi, kasus yang banyak terjadi ketika penerapan sistem pembelajaran online ini di antaranya, tidak meratanya siswa dan orang tua siswa yang pandai mengoperasikan media online, tidak semua orang tua siswa mampu membeli kuota internet, sinyal internet di rumah siswa tidak terjangkau, sebagian besar orang tua murid yang kondisi ekonominya pas-pasan, juga tidak memiliki ponsel pintar atau smartphone sebagai sarana belajar secara online untuk anak mereka dan kurang terkontrol disebabkan tidak langsung tatap muka (Herliandry et al., 2020).

\section{KESIMPULAN}

Dapat ditarik kesimpulan bahwa guru sekolah dasar dalam pembelajaran daring pada kemampuan dan penguasaan penggunaan dan pengetahuan teknologi (TK) adalah ditemukan bahwa guru mampu dan baik dalam menggunakan teknologi untuk pembelajaran, sesuai kemampuan dan kondisi pembelajaran menggunakan WhatsApp, Zoom meeting atau google classroom guru mampu mendownload materi dari Internet atau website dan materi dari youtube dan kemudian guru mampu membagikan dan menshare ke peserta didik dengan menggunakan teknologi, guru sudah mengetahui manfaat dan keunggulan teknologi, guru dapat melakukan interaksi dengan peserta didik pada pembelajaran daring, Guru sekolah dasar dalam pembelajaran daring pada kemampuan Pengetahuan Pedagogik (PK) adalah sudah baik dan tepat, karena guru mampu merancang perangkat pembelajaran, guru mampu menggunakan media pembelajaran yang menarik, Guru menyesuaikan karakter dengan metode yang digunakan serta Guru melakukan evaluasi pembelajaran. Guru sekolah dasar dalam pembelajaran daring pada kemampuan pengetahuan konten (CK) adalah sudah baik dan mampu, dapat dikatakan guru memiliki kemampuan yang baik, dimana guru-guru Guru mampu menyusun materi atau bahan ajar dan Guru menggunakan sumber belajar berbasis teknologi. Saran kepada para guru sekolah dasar agar dapat menggunakan dan meningkatkan 
penguasaan teknologi untuk pembelajaran daring, ditingkatkan baik dari segi pengetahuan, segi pedagogik teknologi dan konten teknologi, serta mempertahankan untuk memperoleh hasil yang baik dan mendukung tujuan pembelajaran pada bagian-bagian TPACK tersebut. Karena sudah baik dan bagus bagi guru sekolah dasar pada kemampuan pedagogis dan pemahaman konten teknologi.

\section{DAFTAR PUSTAKA}

Abazi-Bexheti, L., Kadriu, A., Apostolova-Trpkovska, M., Jajaga, E., \& Abazi-Alili, H. (2018). LMS Solution: Evidence of Google Classroom Usage in Higher Education. Business Systems Research, 9(1), 31-43. https:// doi.org/10.2478/bsrj-2018-0003

Ajizah, I., \& Huda, M. N. (2020). TPACK sebagai bekal guru PAI di Era Revolusi Industri 4.0. Ta'allum: Jurnal Pendidikan 3slam, 3(2), 333-352. https:/ / doi.org/10.21274/taalum.2020.8.2.333-352

Ak, A., Topuz, V., Altikardeş, A., \& Oral, B. (2018). Development of a remote laboratory infrastructure and LMS for mechatronics distance education. Eurasia Journal of Mathematics, Science and Technology Education, 14(6), 2493-2508. https:/ / doi.org/10.29333/ ejmste/ 89947

Anderson, L. W., \& Krathwohl, D. R. (2015). Kerangka Landasan Untuk Pembelajaran, Pengajaran, dan Asesmen (Revisi Taksonomi Pendidikan Bloom) (W. A. Lorin \& R. K. David (eds.)). pustaka pelajar.

Baran, E., Chuang, H. H., \& Thompson, A. (2011). TPACK: An emerging research and development tool for teacher educators. Turkish Online Journal of Educational Technology, $10(4), 370-377$.

Brahma, I. A. (2020). Penggunaan Zoom Sebagai Pembelajaran Berbasis Online Dalam Mata Kuliah Sosiologi dan Antropologi Pada Mahasiswa PPKN di STKIP Kusumanegara Jakarta. Aksara: Jurnal Ilmu Pendidikan Nonformal, 6(2), 97. https:/ / doi.org/10.37905/aksara.6.2.97102.2020

Cahyani, A., Listiana, I. D., \& Larasati, S. P. D. (2020). Motivasi Belajar Siswa SMA pada Pembelajaran Daring di Masa Pandemi Covid-19. IQ (Ilmu Al-Qur'an): Jurnal Pendidikan Islam, 3(01), 123-140. https:/ / doi.org/10.37542/iq.v3i01.57

Cahyati, N., \& Kusumah, R. (2020). Peran Orang Tua Dalam Menerapkan Pembelajaran Di Rumah Saat Pandemi Covid 19. Jurnal Golden Age, Universitas Hamzanwadi, 04(1), 152-159.

Daheri, M., Juliana, Deriwanto, \& Amda, A. D. (2020). Efektifitas WhatsApp sebagai Media Belajar Daring. Jurnal Basicedu, 4(4), 775-783. https:/ / doi.org/10.31004/ basicedu.v4i4.445

Dewi, W. A. F. (2020). Dampak COVID-19 terhadap Implementasi Pembelajaran Daring di Sekolah Dasar. Edukatif: Jurnal Ilmu Pendidikan, 2(1), 55-61. https:/ / doi.org/10.31004/edukatif.v2i1.89

Elianur, C. (2020). Pilihan Media Pembelajaran Daring Oleh Guru Pai Di Bengkulu Tengah. Jurnal As-Salam, 4(1), 37-45.

Erni, S., Vebrianto, R., Miski, C. ut R., Z, Z. A. M., Martinus, \& Thahir, M. (2020). Refleksi proses pembelajaran dimasa pendemi Covid 19 di Pekanbaru: Dampak dan solusi. Bedelau: Journal of Education and Learning, 1-10. https:/ / ejournal.anotero.org/index.php/bedelau/article/view/1

Fauziah, P. I. N., Mansur, R., \& Mustafida, F. (2021). Efektivitas Penggunaan Aplikasi Whatsapp Dalam Pembelajaran Daring Pada Mata Pelajaran Matematika Di SDN Sumberagung 1 Kabupaten Kediri. JPMI: Jurnal Pendidikan Madrasah Ibtidaiyah, 3(2), 101-111.

Fox, R. (2011). Technological Practice and Change in Education. In R. Kwan, C. McNaught, P. Tsang, F. L. Wang, \& K. C. Li (Eds.), International Conference, ICT 2011 (pp. 1-390). Springer Science+Business.

Graham, C. R., Borup, J., \& Smith, N. B. (2012). Using TPACK as a framework to understand teacher candidates' technology integration decisions. Journal of Computer Assisted Learning, 28(6), 530-546. https:/ / doi.org/10.1111/j.1365-2729.2011.00472.x

Hamdani, A. R., \& Priatna, A. (2020). Efektifitas Implementasi Pembelajaran Daring (Full Online) 
Dimasa Pandemi Covid- 19 Pada Jenjang Sekolah Dasar Di Kabupaten Subang. Didaktik: Jurnal Ilmiah PGSD STKIP Subang, 6(1), 1-9. https:/ / doi.org/10.36989/didaktik.v6i1.120

Handarini, O. I., \& Wulandari, S. S. (2020). Pembelajaran Daring Sebagai Upaya Study From Home (SFH) Selama Pandemi Covid 19. Jurnal Pendidikan Administrasi Perkantoran (JPAP), $8(3), 496-503$.

Harde, U., \& Borkar, V. (2020). Use of Information Communication Technology : A Case Study. Our Heritage, 68(23), 130-136.

Herliandry, L. D., Nurhasanah, Suban, M. E., \& Heru, K. (2020). Transformasi Media Pembelajaran Pada Masa Pandemi Covid-19. Jurnal Teknologi Pendidikan, 22(1), 65-70. http://journal.unj.ac.id/unj/index.php/jtp

Koehler, M. J., Mishra, P., \& Cain, W. (2009). What is Technological Pedagogical Content Knowledge (TPACK)? Contemporary Issues in Technology and Teacher Education, 9(1), 13-19. https:// doi.org/10.1177/002205741319300303

Mansyur, A. R. (2020). Dampak COVID-19 Terhadap Dinamika Pembelajaran Di Indonesia. Education and Learning Journal, 1(2), 113-123. https:/ / doi.org/10.33096/eljour.v1i2.55

Mastur, M., Afifulloh, M., \& Dina, L. N. A. B. (2020). Upaya Guru Dalam Melaksanakan Pembelajaran Daring Pada Masa Pandemi Covid-19. JPMI: Jurnal Pendidikan Madrasah Ibtidaiyah, 3, 72-81.

Miles and Huberman. (2014). Qualitative Data Analysis: A Methods Sourcebook (H. Salmon (ed.); Edition 3). SAGE Publications.

Mishra, P., \& Koehler, M. J. (2014). Introducing Technological Pedagogical Content Knowledge. Annual Meeting of the American Educational Research Association, 3, 1-17.

Prasetyo, T., Yektyastuti, R., \& Maulidini, Y. D. (2019). Pengaruh Literasi TIK Terhadap Technological Pedagogical Content Knowledge (TPACK) Guru. Jurnal Ilmiah Untuk Peningkatan Mutu Penddikan, 6(1), 13-20.

Quddus, A. (2020). Implementasi Technological Pedagogical Content Knowledge (TPACK) dalam Pendidikan Profesi Guru (PPG) PAI LPTK UIN Mataram. Jurnal Tatsqif, 17(2), 213230. https:/ / doi.org/10.20414/jtq.v17i2.1911

Rahmadi, I. F. (2019). Technological Pedagogical Content Knowledge (TPACK): Kerangka Pengetahuan Guru Abad 21. Jurnal Pendidikan Kewarganegaraan, 6(1), 65. https:/ / doi.org/10.32493/jpkn.v6i1.y2019.p65-74

Surat Edaran Nomor 4 Tahun 2020 Tentang Pelaksanaan Kebijakan Dalam Masa Darurat Penyebaran COVID-19, 4 (2020).

Rosali, E. S. (2020). Aktifitas Pembelajaran Daring Pada Masa Pandemi Covid-19 Di Jurusan Pendidikan Geografi Universitas Siliwangi Tasikmalaya. Geography Science Education Journal (GEOSEE), 1(1), 21-30.

S. Sirate, S. F., \& Yaumi, M. (2017). Perspektif Belajar Sebagai Landasan Psikologis Dalam Pengembangan Media Dan Teknologi Pembelajaran. Lentera Pendidikan: Jurnal Ilmu Tarbiyah Dan Keguruan, 20(1), 98-111. https:/ / doi.org/10.24252/lp.2017v20n1a8

Salehudin, M. (2020). Dampak Covid-19: Guru Mengadopsi Media Sosial Sebagai E-Learning Pada Pembelajaran Jarak Jauh. Jurnal MUDARRISUNA, 10(1), 1-16.

Salehudin, M., Nurbayani, E., \& Toba, R. (2020). User experience (UX) of multimedia; program of auto play media studio for teacher professional education (PPG). Abjadia: International Journal of Education, 5(2), 111-121. https:/ / doi.org/10.18860/abj.v5i2.8722

Sofyana, L., \& Rozaq, A. (2019). Pembelajaran Daring Kombinasi Berbasis Whatsapp Pada Kelas Karyawan Prodi Teknik Informatika Universitas Pgri Madiun. Jurnal Nasional Pendidikan Teknik Informatika (JANAPATI), 8(1), 81. https:/ / doi.org/10.23887/janapati.v8i1.17204

Srisawasdi, N. (2012). The Role of TPACK in Physics Classroom: Case Studies of Preservice Physics Teachers. Procedia - Social and Behavioral Sciences, 46, 3235-3243. https:/ / doi.org/10.1016/j.sbspro.2012.06.043

Suartama, I. K., Usman, M., Triwahyuni, E., Subiyantoro, S., Abbas, S., Umar, Hastuti, W. D., \& Salehudin, M. (2020). Development of e-learning oriented inquiry learning based on 
character education in multimedia course. European Journal of Educational Research, 9(4), 1591-1603. https:/ / doi.org/10.12973/eu-jer.9.4.1591

Sugiono. (2010). Metode Penelitian Pendidikan; Pendekatan Kuantitatif, Kualitatif dan RED (cetakan ke). Alfabeta, CV.

Suwendra, I. W. (2018). Metodologi Penelitian Kualitatif dalam Ilmu Sosial, Pendidikan, Kebudayaan, dan Keagamaan. In NilaCakra Publishing House, Bandung. NILACAKRA.

Syah, R. H. (2020). Dampak Covid-19 pada Pendidikan di Indonesia: Sekolah, Keterampilan, dan Proses Pembelajaran. SALAM: Jurnal Sosial Dan Budaya Syar-I, 7(5). https:/ / doi.org/10.15408/sjsbs.v7i5.15314

Wahyono, P., Husamah, H., \& Budi, A. S. (2020). Guru profesional di masa pandemi COVID-19: Review implementasi, tantangan, dan solusi pembelajaran daring. Jurnal Pendidikan Profesi Guru, 1(1), 51-65. http:/ / ejournal.umm.ac.id/index.php/jppg/article/view/12462

Wardani, A., \& Ayriza, Y. (2020). Analisis Kendala Orang Tua dalam Mendampingi Anak Belajar di Rumah Pada Masa Pandemi Covid-19. Jurnal Obsesi : Jurnal Pendidikan Anak Usia Dini, 5(1), 772. https:// doi.org/10.31004/obsesi.v5i1.705

Widiyono, A. (2020). Efektifitas Perkuliahan Daring (Online) pada Mahasiswa PGSD di Saat Pandemi Covid 19. Jurnal Pendidikan, 8(2), 169-177. https:// doi.org/10.36232/pendidikan.v8i2.458

Wilson, A. (2020). Penerapan Metode Pembelajaran Daring ( Online ) Melalui Aplikasi Berbasis Android Saat Pandemi. SAP (Susunan Artikel Pendidikan), 5(1), 66-12.

Zimmerman, E. (2010). Creativity And Art Education: A Personal Journey in Four Acts. Art Education, 63(5), 84. 